\title{
Basis Transformasi Tradisi Pesantren Salaf di Era Modern (Kajian Semiotika Barthes dan Dekonstruksi Derrida)
}

\author{
Hawwin Muzakki \\ Institut Agama Islam Negeri Ponorogo \\ hawwin100@gmail.com \\ Khoirul Mudawinun Nisa' \\ Madrasah Aliyah Negeri 2 Tulungagung \\ mudawinunnisa@gmail.com
}

Naskah diterima: 24 Maret 2020| Naskah disetujui: 22 April 2020

\begin{abstract}
Pesantren has contributed to a system of values of local wisdom that has become a tradition and is believed to be a core value and belief. However, not a few pesantren traditions are underestimated, valued by the Orientalists as old-fashioned, traditional, sincretic, etc. The existence of a shift in the view of the pesantren tradition, encourages authors to deconstruct salaf pesantren traditions using the study of Barthes's semiotics and Derrida's deconstruction theory analysis by: 1) Finding the meaning of denotation and connotation through signs, signifier and signified, 2) Tracing the elements of aporia (paradoxical meaning, contradictory meaning, and irony meaning), and 3) Reversing or changing the (conventional) meanings. The results of the study concluded that: 1) The traditions that have been developed in the Salaf pesantren are the accumulated interpretations that have been passed on by the ancestors as the treasures of human psychology (al-makhzun al-nafs) which act as guide tools in a boarding school environment; 2) analysis of the deconstruction of the salaf pesantren tradition is done by severing the epistemological relationship to all authorities that shape the knowledge tradition by overhauling the standard and frozen relations system into a fluid system of relations, further accounted for giving reasonable sides in all the traditions that developed within.
\end{abstract}

Keywords: Semiotics, Roland Barthes, Deconstruction, Jacques Derrida, Pesantren Tradition

\begin{abstract}
Abstrak
Pesantren telah melahirkan sistem nilai-nilai kearifan lokal yang menjadi tradisi dan diyakini sebagai nilai dasar (core belief and core values). Namun, tidak sedikit tradisi-tradisi pesantren dipandang sebelah mata, kolot, sinkretis, jumud dan kuno oleh kaum orientalis. Adanya pergeseran pandangan tersebut, mendorong penulis untuk mendekonstruksi tradisi pesantren salaf menggunakan kajian semiotika Barthes dan pisau analisis teori dekonstruksi Derrida dengan cara: 1) Mencari makna denotasi dan konotasi lewat tanda, penanda dan petanda, 2) Melacak unsurunsur aporia (makna paradoks, makna kontradiktif, dan makna ironi), dan 3) Membalikkan atau merubah makna-makna yang sudah dikonvensionalkan. Penelitian kualitatif ini berlokasi di Pesantren Darussalam Mekar Agung Madiun. Melalui observasi, wawancara dan studi dokumentasi, disimpulkan bahwa: 1) Tradisi-tradisi yang telah berkembang di pesantren salaf merupakan akumulasi interpretasi yang telah diwariskan para leluhur sebagai khazanah kejiwaan manusia (al-makhzun al-nafs) yang menjadi pedoman dan piranti dalam lingkungan pesantren; 2)
\end{abstract}


analisis dekonstruksi tradisi pesantren salaf dilakukan dengan memutuskan hubungan epistemologis terhadap segala otoritas yang membentuk tradisi pengetahuan dengan merombak sistem relasi yang baku dan beku, menjadi sistem relasi yang cair dan dinamis, dari yang mutlak menjadi relatif, dari ahistoris menjadi historis yang selanjutnya dipertanggungjawabkan untuk memberi sisi-sisi masuk akal (reasonable) dalam segenap tradisi yang berkembang.

Kata Kunci: Semiotika, Roland Barthes, Dekontruksi, Jacques Derrida, Tradisi Pesantren.

\section{Pendahuluan}

Pada masa-masa awal pembentukannya, pesantren tumbuh dan berkembang dengan menyandang ciri-ciri tradisionalitasnya. Akan tetapi pada masa-masa berikutnya, pesantren sebagai lembaga pendidikan Islam telah mengalami perkembangan bentuk sesuai dengan perubahan zaman, terutama sekali adanya dampak kemajuan ilmu pengetahuan dan teknologi, yang tentu saja berdampak pula terhadap masyarakat penyokongnya. Termasuk juga ketika di masa penjajahan, pesantren menjadi salah satu lokus yang berperan menggerakkan rakyat, baik dalam pengertian pergerakan alamiah (mobilitas fisik) maupun moral (perlawanan terhadap kolonialisme), sebagaimana dikaji Rohmatulloh (2018). Namun, sejarah membuktikan bahwa dinamika pesantren tersebut tidak menghilangkan keaslian dan kesejatian tradisinya. Dewasa ini, secara faktual ada tiga tipe pesantren yang berkembang dalam masyarakat, yaitu pesantren tradisional, pesantren modern, dan pesantren komprehensif (Ghazali, 2001, p. 14).

Pesantren tradisional masih tetap mempertahankan bentuk aslinya dengan semata-mata mengajarkan kitab-kitab berbahasa Arab yang ditulis oleh para ulama abad Pertengahan (kitab kuning). Pola pengajarannya dengan menerapkan sistem halaqah (kelompok pengajian) yang dilaksanakan di masjid atau surau. Pesantren modern merupakan pengembangan tipe pesantren menghadapi perubahan zaman, karena orientasi belajarnya cenderung mengadopsi seluruh sistem belajar secara klasikal dan meninggalkan sistem belajar tradisional. Sedangkan pesantren komprehensif merupakan sistem pendidikan dan pengajaran gabungan antara pesantren tradisional dan pesantren modern. Di dalam pesantren tipe terakhir ini diterapkan pendidikan dan pengajaran kitab kuning secara halaqah, namun secara reguler sistem persekolahan terus dikembangkan (Ghazali, 2001, pp. 14-15).

Pada perkembangan mutakhirnya, pesantren (terutama pesantren tradisional) dianggap sebagai lembaga edukasi yang kurang relevan dan tidak menjanjikan masa depan. Sistem dan metodologi pesantren dianggap ketinggalan zaman bila tidak berubah mengikuti perkembangan modern. Penilaian masyarakat yang demikian itu sempat mengalami pembenaran di awal-awal masa modernisasi pendidikan di Indonesia. Akan tetapi, tatkala asumsi dan justifikasi tersebut digeneralisasi atas pesantren era sekarang, tentu hal tersebut akan terkesan sebagai bentuk penilaian yang amat tergesa-gesa (Hafidhoh, 2016, p. 97).

Barat dengan segala hegemoninya melakukan kategorisasi terhadap pengetahuan Islam, melalui perangkat ilmu sosiologi dan antropologi untuk melakukan penyelidikan masyarakat dan budaya, berkontribusi besar dan memiliki andil besar terhadap pengkategorian masyarakat Timur (Islam) (Nisa, 2018, p. 102). Barat dengan perangkat agennya yakni para orientalis, melakukan kajian terhadap dunia timur dengan maksud to know, to truth, and to power. 
Pada awalnya para orientalis memahami bagaimana dunia Timur sehingga mereka belajar memahami mengenai keilmuan dan kebudayaan orang Timur sampai menjadi benar-benar ahli. Tahapan ini disebut to know. Setelah mengetahui khazanah intelektual orang Timur, orientalis membandingkan antara peradaban Timur dan peradaban Barat, dengan menunjukkan segala kelebihan dan kebenaran dari teori yang dibawa dari Barat. Munculnya istilah modern dan tradisi adalah salah satu kontruksi dari to truth. Semakin dekat dengan Barat, berarti dikatakan modern, sebaliknya semakin menjauh dari peradaban Barat dikatakan tradisional. Setelah mengetahui kelebihan dan kebenaran keilmuan dan peradaban tinggi dari Barat, tahapan selanjutnya yaitu melakukan to power, penguasaan Barat terhadap dunia Timur. Hegemoni dan pemahaman Barat sebagai pusat (Barat sentris), merasuk ke segala penjuru kehidupan dunia Timur termasuk bidang pemikiran (Foucault, 1981, p. 132).

Pengelompokan-pengelompokan oleh tokoh orientalis dalam mengkaji masyarakat Islam benar-benar terjadi di Indonesia. Pengelompokan antara tradisional dan modern, Kiai dan Profesor, kaum sarungan dengan kaum seragam, penggolongan masyarakat Islam menjadi santri, priyayi dan abangan, membuat masyarakat saling berhadap-hadapan dan bermusuhan. Barat melakukan konstruksi wacana untuk memecah belah Islam antara lain dengan memunculkan wacana Islam Modern dan Islam Tradisionalis. Islam Tradisional dikatakan Islam yang belum sempurna dan sinkretis. Pemahaman tersebut juga masuk ke pesantren, dengan mengatakan pesantren salaf dengan segala tradisinya jumud, kolot dan ketinggalan zaman. Karena produk pesantren salaf merupakan upaya dari Islam Tradisional untuk mempertahankan ajaran dan tradisinya.

Kegelisahan penulis untuk melakukan proses dekonstruksi wacana tradisi pesantren dengan merombak makna konotasi yang digaungkan oleh kaum orientalis menjadi makna denotasi yang sesungguhnya, merombak sistem relasi yang baku dan beku, menjadi sistem relasi yang cair dan dinamis, dari yang mutlak menjadi relatif, dari ahistoris menjadi historis yang selanjutnya dipertanggungjawabkan untuk memberi sisi-sisi masuk akal (reasonable) dalam segenap tradisi yang berkembang di pesantren salaf sehingga tradisi-tradisi yang telah berkembang tersebut berbunyi sesuai dengan konteks aslinya.

Berdasarkan eksplorasi penelitian tentang "Basis Transformasi Tradisi Pesantren Salaf di Era Modern (Kajian Analisis Semiotika Roland Barthes dan Dekonstruksi Jacques Derrida)", penulis berkesimpulan bahwa belum ada kajian yang secara langsung yang membahas tentang dekonstruksi tradisi pesantren salaf. Thonthowi (2008, p. 150) meneliti tentang kaitan pendidikan dan tradisi pesantren, kesimpulan penelitian mengungkapkan bahwa tradisi dan pendidikan itu selalu saling berkelindan dan saling mempengaruhi, tradisi yang sudah menyatu dalam diri masyarakat bisa mewujud dalam aspek agama, sosial, ekonomi, budaya yang semuanya itu sebetulnya adalah hasil dari proses pendidikan.

Mengenai tradisi pesantren, Mukhibat (2015) menyimpulkan bahwa pesantren harus mampu melakukan continuity and change untuk merekatkan nilai-nilai lokalitas, nasionalitas, dan globalitas. Dengan kata lain, masa depan pesantren ditentukan oleh model pendidikan yang menautkan antara nilai-nilai kultural pesantren, kebangsaan, dan isu-isu kemanusiaan global.

Penelitian bertema dekontruksi di pendidikan Islam, Suyatno (2012, p. 121) menelitinya dengan kesimpulan sistem pendidikan di Indonesia perlu segera didekonstruksi. Dekonstruksi dualisme sistem tersebut harus didasari oleh pikiran yang jernih dan pertimbangan yang matang dan 
menuntut peran serta berbagai pihak yang terlibat dan berkepentingan yang pada akhirnya nanti semua lembaga pendidikan berada di bawah satu payung kementerian yakni Kementerian Pendidikan Nasional dan Kebudayaan.

Belum ada karya penelitian yang secara khusus menggali tradisi pesantren salaf, yang oleh beberapa orang dianggap kolot atau ketertinggalan zaman menggunakan dekonstruksi wacana Jacques Derrida agar memunculkan makna tradisi pesantren yang sesuai dengan makna aslinya, bukan terhegemoni, tidak kaku dan tidak kolot, namun memang benar keluar dari konteks asli wacana tradisi pesantren tersebut. Dekonstruksi ulang tersebut agar pesantren salaf dengan segala tradisinya sesuai dengan makna aslinya, yaitu menjaga sistem nilai-nilai kearifan lokal yang menjadi tradisi dan diyakini sebagai nilai dasar (core belief and core values).

Penelitian ini berlokasi di Pondok Pesantren Salaf Darussalam Mekar Agung Kabupaten Madiun Jawa Timur, dengan alasan pemilihan lokasi tersebut karena Pondok Pesantren ini menggunakan metode salafiyah yang menganut faham "Ahlussunnah Wal Jama'ah" melestarikan hal-hal lama yang baik dan mengembangkan hal-hal baru yang lebih baik dan bermanfaat, serta menekankan pada pendidikan Akhlak Salafussholih dan Kholafussholih. Dalam penelitian ini informan ditentukan secara purposive. Penulis mengkategorikan informan sebagai informan utama dan informan tambahan. Pengumpulan data yang digunakan dalam penelitian ini menggunakan tiga teknik pengumpulan data, yaitu observasi, wawancara semi terstruktur dan dokumentasi.

Metode yang digunakan dalam penelitian ini adalah metode kualitatif dengan jenis penelitian deskriptif. Pendekatan yang digunakan dalam penelitian ini adalah semiotika kultural oleh Roland Barthes, dimana semiotika kultural merupakan semiotika yang menelaah sistem tanda pada kehidupan sosial budaya masyarakat tertentu (Hoed, 2011, p. 13). Pemilihan pendekatan ini didasarkan pada obyek kajian yang diteliti mengenai tanda berupa segala gerak, perilaku, pemahaman dan teks "tradisi pesantren". Oleh karena itu, pada penelitian ini pendekatan semiotika kultural Barthes dijadikan metode, dimana dalam pengumpulan datanya untuk mengkaji teks berupa tradisi yang ada di pesantren.

Rumusan masalah dalam penelitian ini untuk menyelidiki 1) Bagaimana tradisi yang berkembang di Pesantren? 2) Bagaimana mendekonstruksi tradisi pesantren? dengan tujuan penelitian untuk melakukan antitesis terhadap pewacanaan kaum orientalis terhadap tradisi pesantren sekaligus melakukan proses dekontruksi tradisi pesantren salaf agar tetap menjadi core belief and core values di masyarakat Indonesia.

\section{Pendekatan Semiotika Kultural Roland Barthes}

Dalam pendekatan semiotika Barthes, model yang digunakan terfokus pada signifikasi dua tahap. Pertama, adanya denotasi yang dikenal sebagai makna secara umum di masyarakat. Kedua, makna konotasi yang merupakan makna baru yang diberikan pemakai tanda sesuai keinginan, latar belakang pengetahuan dan konvensi baru dalam masyarakat. Maka makna baru inilah yang menjadi tanda konotasi atau yang disebut Barthes dengan bahasa mitos. 


\begin{tabular}{|c|c|c|c|c|}
\hline \multirow{3}{*}{$\begin{array}{l}\text { Bahasa } \\
\text { mitos }\end{array}$} & $\begin{array}{l}\text { Denotasi } \\
\text { (makna } \\
\text { Primer) }\end{array}$ & 1. Penanda & 2. Petanda & \\
\hline & \multirow{2}{*}{$\begin{array}{l}\text { Konotasi } \\
\text { (makna } \\
\text { Selunder) }\end{array}$} & \multicolumn{2}{|l|}{$\begin{array}{l}\text { 3. Tanda } \\
\text { I PENANDA }\end{array}$} & II. PETANDA \\
\hline & & \multicolumn{3}{|c|}{ III. TANDA } \\
\hline
\end{tabular}

Gambar 1: Signifikansi mitos Bartes

Sumber: (Barthes, 2004, p. 162)

Adapun langkah-langkah menganalisis data semiotika dalam penelitian ini adalah:

1. Melakukan pembacaan berulang kali pada obyek penelitian.

2. Analisis data secara individual untuk pemaknaan semiotika tahap pertama.

3. Analisis data secara kelompok untuk pemaknaan semiotika tahap dua, guna menghasilkan pemaknaan konotasi.

4. Menarik kesimpulan dari interpretasi data.

\section{Teori Dekontruksi Jacques Derrida}

Dekonstruksi yang dikemukakan oleh Derrida (1976) adalah penolakannya terhadap logosentrisme dan fonosentrisme yang secara keseluruhan melahirkan oposisi biner dan cara-cara berpikir lainnya yang bersifat hierarkis dikotomis. Dekonstruksi adalah cara membaca teks, sebagai strategi. Dekonstruksi tidak semata-mata ditunjukkan terhadap tulisan, tetapi semua pernyataan kultural sebab keseluruhannya pernyataan tersebut adalah teks yang dengan sendirinya sudah mengandung nilai-nilai, prasyarat, ideologi, kebenaran, dan tujuan-tujuan tertentu. Dekonstruksi dengan demikian tidak terbatas hanya melibatkan diri dalam kajian wacana, baik lisan maupun tulisan, melainkan juga kekuatan-kekuatan lain yang secara efektif mentransformasikan hakikat wacana. Menurut dekonstruksi adalah testimoni terbuka kepada mereka yang kalah, mereka yang terpinggirkan oleh stabilitas rezim bernama pengarang. Maka, sebuah dekonstruksi adalah gerak perjalanan menuju hidup itu sendiri (Fayyadl, 2005, p. 232; Muzakki, 2017, p. 37)

Secara skematik teori dekonstruksi Derrida terdiri dari 3 langkah, pertama mengidentifikasi hierarki oposisi dalam teks yang biasanya terdapat peristilahan yang diistimewakan secara sistematik. Kedua, oposisi-oposisi tersebut dibalik dengan menunjukan adanya saling ketergantungan diantara yang saling berlawanan itu sekaligus mengusulkan privilese secara terbalik. Ketiga memperkenalkan sebuah istilah atau gagasan baru yang tidak bisa dimasukkan dalam kategori lama.

Differance adalah istilah yang diciptakan oleh Derrida tahun 1968 dalam kaitannya dengan pemahamannya mengenai ilmu bahasa Saussure dan antropologi Levi-Strauss. Kata différance bagi Derrida dikenalkan untuk melihat lebih dari sebuah bahasa lama yang biasa disebut différence (fr), dimana kata tersebut memiliki kesamaan dari kata difference (en) yang diartikan perbedaan. Konsepsi kata différence dan différance, jika dilafalkan dengan suara akan memiliki kesamaan bunyi (deferas) dalam bahasa Perancis (Fayyadl, 2005, p. 111). Kedua kata tersebut tidak terlihat perbedaannya dalam tuturan, namun akan terlihat perbedaan maknanya ketika kedua kata tersebut 
tertulis. Hal itulah yang membuat munculnya konsep différance dipakai dalam arti yang lebih berbeda, différance dipakai untuk penundaan terhadap makna.

Menurut gagasan Derrida mengenai Différance memiliki tiga pengertian, pertama, mengenai to differ (en), untuk membedakan sifat dasarnya suatu makna. Dalam kajian ini melihat bahwa fenomena teks tradisi pensantren yang dilakukan oleh para orientalis menunjukan pembedaan episteme yang dibangun melalui pemaknaan tersebut. Kedua, differe (fr), yang merupakan untuk menyebarkan makna tersebut. Seperti saat para orientalis mempublikasikan hasil risetnya tentang tradisi pesantren yang kolot, jumud dan tidak mengikuti perkembangan zaman, maka makna dari teks tersebut mungkin akan diterima atau tidak oleh masyarakat. Ketiga, to defer (en), merupakan penundaan makna. Pada fenomena pemaknaan tradisi pesatren oleh para orientalis ini melihat bahwa tradisi pesantren di Indonesia terkesan jumud, tradisional, kolot, tidak mengikuti perkembangan zaman membuat makna baru dari sebuah tradisi pesantren tersebut. Sehingga makna tradisi pesantren yang diyakini sebagai nilai dasar (core belief and core values) oleh masyarakat menjadi hilang maknanya digantikan oleh makna sinkretis, kolot, jumud, tidak mengikuti perkembangan zaman.

\section{Pemaknaan Konotatif terhadap Tradisi Pesantren}

Pembahasan kali ini nantinya akan mengungkap tradisi pesantren, menggunakan pendekatan semiotika kultural Roland Barthes dan dekonstruksi milik Jacques Derrida. Pesantren sebagai lembaga asli Indonesia yang memiliki corak tersendiri dibandingkan dengan lembaga lain, mulai dari sistem pengajarannya, transmisi keilmuan dan kebudayaannya serta memiliki peran besar dalam ikut serta mencerdaskan kehidupan bangsa Indonesia. Perkembangan pesantren juga tidak bisa dilepaskan dari pemikiran intelektual para ulama dengan jaringan ulama Haramain. Jaringan tersebut menjadikan pesantren sebagai basis pendidikan yang mengedepankan intelektual dan pembentukan kepribadian santri. Pesantren menurut pengertian dasarnya tempat belajar para santri (Hasbullah, 1996, p. 40).

Keberadaan Wali Songo merupakan pelopor berdirinya pesantren dalam perkembangan Islam di Jawa. Wali Songo melakukan proses yang tak berujung, gradual dan berhasil dalam menciptakan suatu tatanan masyarakat santri yang saling damai dan berdampingan. Satu pendekatan yang sangat berkesesuaian dengan filsafat hidup masyarakat Jawa yang menekankan stabilitas, keamanan dan harmoni. Pendekatan Wali Songo, yang kemudian melahirkan pesantren dengan segala tradisinya, perilaku dan pola hidup saleh dengan mencontoh dan mengikuti para pendahulu yang terbaik, mengarifi budaya dan tradisi lokal merupakan ciri utama masyarakat pesantren (Mastud, 2002, p. 227). Dengan semakin menjamurnya tradisi-tradisi di pesantren baik yang berkaitan dengan sistem pembelajaran, hubungan antar kiai, ustadz dan santri maupun kondisi lingkungan pesantren memunculkan pemaknaan baru oleh kaum orientalis.

Dalam kehidupan sehari-hari sering kita mendengar istilah "tradisi" seperti ungkapan tradisi jawa, tradisi kraton, tradisi petani, tradisi pesantren dan lain-lain. Tetapi istilah "tradisi" biasanya secara umum dimaksudkan untuk menunjuk kepada suatu nilai, norma dan adat kebiasaan yang berbau lama, dan yang lama tersebut hingga kini masih diterima, diikuti bahkan dipertahankan oleh masyarakat tertentu. Namun demikian, tradisi yang penulis maksudkan dalam uraian ini lebih banyak mengacu kepada tradisi keagamaan pesantren salafi mengingat model kedua pesantren ini, 
yang di dalam pengkajian kitab, pengambilan dalil-dalil punya tradisi khas, yakni tidak begitu memerdulikan kekuatan atau kesahihan dalil menjadikan mereka punya tradisi dalam bidang pendidikan untuk menggunakan kitab-kitab yang dianggap -oleh sementara kalangan sebagai kurang valid seperti kitab Ushfûriyah, Durrah al-Nâshihîn, 'Uqud al-Lujain, Washiyyah alMushthafa, Qurrah al 'Uyun dan lain-lain. Kitab teks tadi umumnya tidak mencantumkan klasifikasi hadith serta tidak menguji keabsahan para periwayat yang mentransmisikannya (Thonthowi, 2008).

Seperti tradisi dalam pesantren salaf semisal dalam berpakaian yang berupa sarung, kopyah, baju takwa, sorban, imamah, klompen/ bengkyak, halâl bi halâl, tahlilan, istighâtsah, pengajian, semisal pengajian Rebo Kliwon, Jum'at Legi, memainkan alat musik hadrah, japen dan lain-lain. Berdasarkan pendekatan Roland Barthes, penulis simpulkan bahwa tradisi pesantren tersebut sebagai penanda (signifier) lembaga tradisional yang menghasilkan makna konotatif negatif, dan menjadi mitos dengan petanda (signified) bahwa lembaga ini kolot, ketinggalan zaman, tertinggal, kaku dan sebagainya.

Teks "tradisi pesantren" bentuk pertama ini disebut dengan denotasi seperti dalam konsep mitologi Roland Barthes bahwa denotasi yaitu makna yang dikenal secara umum melalui penanda, petanda dan tanda. Makna umum yang dikenal oleh masyarakat bahwa tradisi pesantren diyakini telah melahirkan nilai-nilai dasar core belife and core values pada setiap aspek kehidupan. Dari hal tersebut memunculkan kelompok-kelompok yang memaknai secara berbeda, yaitu kelompok orientalis.

Kelompok orientalis adalah seorang yang melakukan kajian tentang masalah ketimuran (Islam), sehingga makna teks bentuk pertama juga diterima oleh kelompok tersebut. Namun, kaum orientalis juga memiliki pemahaman tersendiri dalam memaknai tradisi pesantren dalam pengkajiannya. Dalam hal ini tradisi pesantren yang dimaknai sebagai pencetak nilai-nilai dasar core belife and core values menjadi bergeser maknanya tradisional yang bermakna konotasi negatif berupa sinkretis, jumud, kolot dan ketertinggalan zaman. Pada kesimpulannya, mengadopsi modernitas adalah sebuah kewajiban dan harus meninggalkan hal-hal yang tradisional.

Makna tersebut mengalami dekonstruksi, yang secara umum diurai oleh kaum orientalis melalui teks-teks dan simbol tertentu. Dari proses dekonstruksi mengalami apa yang disebut oleh Derrida tentang différance, dimana dalam différance mempunyai cara kerja tersendiri yaitu to differ (en), différe (fr) dan to deffer (en). Teks "tradisi pesantren" yang dimaknai oleh para orientalis seperti Cristian Snouck Hurgronje, P.J Zoutmulder, Clifford Geertz, Herry J Benda, Benedict Anderson, hingga Mark Woodward, menempatkan amatannya dengan menyebut Islam tradisional sebagai Islam sinkretis (Saleh, 2004, pp. 35-36).

Fauzan Saleh sebagaimana dikutip oleh Howard S. Federspiel selaku promotor doktoralnya di McGill University, Kanada, menyimpulkan Islam sinkretis dengan sebutan "Islam yang belum sempurna," (Saleh, 2004, p. 6). Dari kutipan di atas, jelas bahwa Islam sinkretis sebagai identitas Islam tradisional disebut sebagai Islam yang belum sempurna, sekaligus tidak memahami ajaran Islam yang sebenarnya. Pandangan itu pula yang masuk dan tersematkan dalam pesantren salaf dengan segala tradisinya, dengan memberikan stempel "tradisional". Celakanya, Islam sinkretis sebagai sebuah pemahaman Islam yang belum sempurna dianut oleh beberapa tokoh Islam di Indonesia. Pandangan tersebut adalah bentuk simpulan yang tidak lepas dari hasil produksi 
pengetahuan para antropolog yang diproduksi oleh tokoh orientalis. Simpulan ini merupakan usaha mereka memberi arti terhadap fenomena keagamaan kelompok tradisional melalui amatan faktual budaya. Pendeknya, mereka memaknai manusia beragama hanya pada ekspresi budaya. Yakni, sejauh manusia beragama memiliki peran sosialnya yang berkesesuaian dengan kebudayaannya.

Teks "tradisi pesantren" yang dimaknai sebagai pencetak core belife and core values menjadi bergeser dan terurai berdasarkan prosesnya. Kemudian dari proses différance tersebut memunculkan episteme teks dari kaum orientalis dengan pemikiran yang kritis untuk membuat makna baru. Dari munculnya teks tradisi pesantren baru merupakan teks bentuk kedua yang disebut konotasi, dimana konotasi adalah makna baru yang diberikan pemakai tanda sesuai keinginan, latar belakang pengetahuan atau kesepakatan baru yang ada dalam masyarakat. Hal itu yang terlihat dengan adanya kaum orientalis yang memberikan makna baru terhadap tradisi pesantren. Selanjutnya dari makna konotasi ini yang membuat bentuk tanda baru yang disebut mitos, sehingga teks tradisi pesantren dikatakan jumud, kolot, menghegemoni, dan ketinggalan zaman, menjadi sebuah mitos di lingkungan teks tersebut beredar.

Berdasarkan uraian di atas berikut gambarannya:

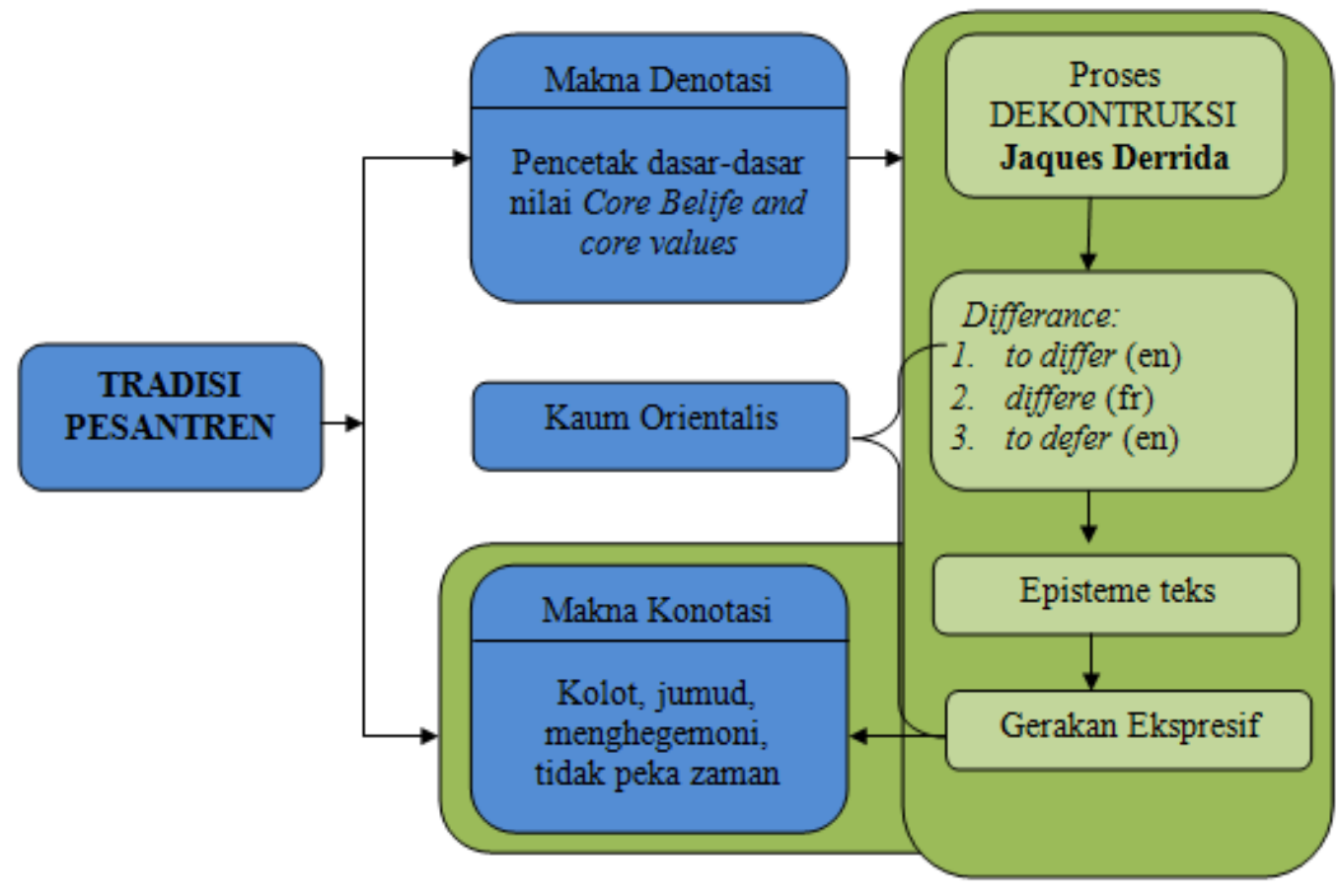

Gambar 2. Pembacaan Orientalis terhadap Tradisi Pesantren

\section{Tradisi Pesantren di Pesantren Darussalam Mekar Agung Madiun}

\section{Profil Pesantren}

Pondok Pesantren "Darussalam Mekar Agung" adalah salah satu dari cukup banyak lembaga pesantren yang ada di Kabupaten Madiun yang didirikan sejak tahun 1982 M / 1402 H oleh Al Maghfurlah KH. Muhammad Thohir Besyari, tepatnya di Dusun Kepuh Beluk, Desa Pucanganom, Kecamatan Kebonsari, Kabupaten Madiun. Pondok Pesantren ini menggunakan metode salafiyah yang menganut faham "ahlussunnah wa aljamaah", utamanya prinsip al- 
muhafadhah ala-l-qadim al-shalih wal-akhdzu bi-l-jadid al-ashlah (melestarikan hal-hal lama yang baik dan mengembangkan hal-hal baru yang lebih baik dan bermanfaat), serta menekankan pada pendidikan Akhlak Salafussholih dan Kholafussholih (Pengurus, 2019). Metode ini diterapkan di Pondok Pesantren "Darussalam Mekar Agung" dalam bentuk adanya pendidikan formal yang mengajarkan ilmu-ilmu umum atau hal-hal yang baik sesuai dengan tuntutan hidup di era globalisasi, dan juga pendidikan Non Formal yang berupa Madrasah Diniyah yang khusus mengajarkan ilmu-ilmu agama islam dengan pengkajian pada kitab-kitab kuning.

Selain itu juga ada bentuk pendidikan berupa kursus, diklat, ketrampilan dan lain-lain yang sekiranya di perlukan oleh santri sebagai bekal hidupnya kelak. Dengan demikian santri-santri Pondok Pesantren "Darussalam Mekar Agung" dapat mempelajari disiplin ilmu secara utuh dalam arti tidak hanya mempelajari ilmu-ilmu agama tetapi juga mempelajari ilmu-ilmu yang bersifat umum, demi terwujudnya tujuan jangka pendek keselamatan kebahagiaan di dunia dan tujuan jangka panjang keselamatan dan kebahagiaan abadi di akhirat kelak. Adapun visi pondok pesantren Darussalam Mekar Agung adalah "Berilmu, Beramal, Beriman, Bertaqwa dan Berakhlaqul Karimah".

\section{Tradisi Pesantren yang berkembang}

Gus Dur pernah mengemukakan dalam sebuah tesis bahwa pesantren dianggap sebagai sub-kultur: sebuah komunitas sosial yang memiliki budaya yang khas. Kekhasan pesantren ini ditengarai beberapa hal, yaitu pertama, pola kepemimpinan pesantren yang mandiri tidak terkooptasi oleh negara. Kemudian, kitab-kitab rujukan yang dikaji berasal dari kitab-kitab klasik yang dikenal dengan sebutan kitab kuning dan yang terakhir adalah (value system) sistem nilai yang dipilih.

Demikian juga Pondok Pesantren Darussalam Mekar Agung Kabupaten Madiun yang mengidentikkan dirinya sebagai pondok salafiyah menjadi fokus utama penulis untuk menelisik tradisi pesantren yang berkembang yang dianggap sebagai penopang kuat atas budaya yang dikembangkan di pesantren. Adapun tradisi-tradisi pesantren yang berkembang dan direvitalisasi oleh pesantren ini adalah sebagai berikut:

a. Sikap patuh dan tunduk secara mutlak kepada dhawuh (perkataan) kiai. Bentuk ta'dhim seorang santri kepada kiai terimplementasi pada ungkapan etika jawa yang berbunyi sabda pandhita ratu: apa kata kiai adalah kebenaran yang kucari. Jika sang kiai menyuruh santri untuk pergi ke barat maka santri langsung melaksanakan perintah tersebut, tanpa bertanya: untuk apa ke Barat? Kenapa ke Barat? Maupun ada apa di Barat? Karena santri sudah meyakini apapun perintah kiai sudah pasti benar dan baik untuknya. Keagungan wawasan keilmuan kiai merupakan salah satu alasan bentuk ta'dhim santri terhadap kiai, dengan bersikap patuh dan tunduk terhadap kiai, para santri mengharap barakah ilmunya, kehidupannya, dan rezekinya.

Kiai dalam pandangan santri adalah seorang yang menjadi pedoman, baik dari segi keilmuan, suri tauladan dan hal yang lainnya. Jadi tidak mungkin seorang kiai menjerumuskan santrinya. Keyakinan itulah yang ditanamkan kepada seorang santri yang telah mentradisi secara turun temurun tersebut berdasarkan atas potongan bait dalam kitab Alfiyyah: وكل من لم ينتقد لم ينتفع (dan setiap orang yang tidak ada keikhlasan, kidmat, dan 
tekad, tidak akan beroleh manfaat atau berkah). Bentuk ta'dhim seorang santri terhadap kiai antara lain diaplikasikan dalam bentuk: a. Menata sandal kiai, b. Tidak pernah mau menduduki maqam kiai (tempat duduk, tempat sholat dll), c. Rebutan bekas air minum kiai, serta d. Tidak mau berjalan mendahului kiai. Adapun alasan pelestarian tradisi-tradisi tersebut adalah, pertama, mengikuti ajaran para pendahulu yang telah diwariskan para leluhur sebagai khazanah kejiwaan manusia (al-makhzun al-nafs) yang menjadi pedoman dan piranti dalam lingkungan pesantren. Kedua, untuk menjaga akhlakul karimah sesuai dengan visi pesantren berilmu, beramal, berakhlak karimah, ketiga, melestarikan hal-hal lama yang baik dan mengembangkan hal-hal baru yang lebih baik dan bermanfaat, keempat, ajaran dari pelajaran kitab-kitab klasik (Ma'sun Rifai, Wawancara, 2019).

b. Teknik pengajaran utama yang diaplikasikan di pesantren Darussalam Mekar Agung adalah sorogan dan bandongan. Sorogan adalah pelajaran yang diberikan secara individual. Kata sorogan berasal dari bahasa jawa sorog yang berati menyodorkan. Seorang santri menyodorkan kitabnya kepada seorang kiai untuk meminta diajari. Oleh karena sifatnya pribadi, santri harus menyiapkan diri sebelumnya mengenai apa yang akan diajarkan kiai. Teknik sorogan telah terbukti efektif sebagai langkah pertama bagi seorang murid yang bercita-cita menjadi seorang alim. Teknik ini memungkinkan seorang guru mengawasi, menilai dan membimbing secara maksimal kemampuan seorang murid dalam menguasai literatur Arab. Bandongan adalah pelajaran yang diberikan secara berkelompok. Kata bandongan berasal dari bahasa jawa yang berarti berbondong-bondong secara kelompok. Teknik bandongan disebut juga teknik wetonan, yaitu metode kuliah dimana santri mengikiti pelajaran dengan duduk di sekeliling kiai yang menerangkan pelajaran.

Dalam teknik bandongan, seorang tidak harus menunjukkan ia mengerti tentang kitab yang sedang dipelajari. Para kiai biasanya membaca dan menerjemahkan arti secara cepat dan tidak menerjemahkan kata-kata yang mudah. Dengan cara tersebut seorang kiai dapat menyelesaikan kitab-kitabnya dengan cepat. Teknik bandongan ini dimaksudkan untuk santri menengah dan tingi yang sudah pernah mengikuti teknik sorogan secara intensif.

Teknik pembelajaran yang lain adalah Halaqah yakni belajar bersama secara diskusi untuk mencocokkan pemahaman tentang arti terjemah dari isi kitab. Jadi bukan mendiskusikan isi kitab dan terjemahnya yang diberikan oleh kiai itu benar atau salah. Maka yang didiskusikan untuk mengetahui pertanyaan "apa" bukan pertanyaan "mengapa". Kemudian ada juga lalaran yakni belajar sendiri dengan jalan menghafal; biasanya dilakukan di tempat kasual; baik di dekat makam, masjid, atau kamar. Lalaran ini dapat juga disebut teknik hafalan yaitu santri menghafal teks atau kalimat tertentu dari kitab yang dipelajarinya, materi hafalan biasanya berbentuk nazham. Teknik-teknik belajar tersebut berdasarkan pada keyakinan bahwa kitab yang diajarkan adalah benar dan kiai atau ustadz tidak mungkin mengajarkan sesuatu yang keliru dan menyesatkan; jadi sifatnya mekanis, terus menerus dan secara berurutan (tidak melompat-lompat) (Mastuhu, 1994).

\section{Dekonstruksi Tradisi Pesantren}

Kajian dekontruksi dari tradisi pesantren di Pondok Pesantren Darussalam Mekar Agung Madiun menghasilkan makna yang berbeda, baru dan lebih kontekstual dari perspektif pesantren 
sendiri. Tradisi pesantren dibaca atau berbicara dalam perspektif pesantren sendiri. Tradisi pesantren yang beredar di pesantren ini ternyata menggambarkan khazanah intelektual yang mendalam dari dunia pesantren, jauh dari sinkretis, kolot dan ketinggalan zaman.

Tradisi pesantren dengan makna baru itu yaitu menjalankan tradisi berarti:

1. Mengikuti ajaran para pendahulu yang telah diwariskan para leluhur sebagai khazanah kejiwaan manusia (al-makhzun al-nafs) yang menjadi pedoman dan piranti dalam lingkungan pesantren.

2. Menjaga akhlakul karimah sesuai dengan visi pesantren berilmu, beramal, berakhlak karimah.

3. Melestarikan hal-hal lama yang baik dan mengembangkan hal-hal baru yang lebih baik dan bermanfaat,

4. Mengembangkan ajaran dari pelajaran kitab-kitab klasik.

5. Menanamkan pada keyakinan bahwa kitab yang diajarkan adalah benar dan kiai atau ustadz tidak mungkin mengajarkan sesuatu yang keliru dan menyesatkan.

Pandangan tersebut masuk dalam kajian post-tradisionalisme Islam. Mengenai posisi Islam terhadap budaya lokal adalah adanya gagasan tentang pribumisasi Islam. Pribumisasi Islam berusaha untuk menjadikan agama (Islam) dan budaya lokal tidak saling mengalahkan melainkan mewujud dalam pola nalar religiositas yang tidak lagi mengambil bentuknya yang otentik dan murni (pure) dari agama dan berusaha menjadi jembatan yang selama ini memisahkan antara keduanya (agama dan budaya). Budaya sebagai wadah, Islam sebagai ajaran utama. Kita beragama Islam namun tidak perlu menyerap semua budaya Arab, cukup menjadi Indonesia dalam beragama Islam (Rahmat, 2003, p. 9).

Upaya pribumisasi Islam tersebut didasarkan pada logika bahwa dalam setiap universalisasi selalu berangkat dari sesuatu yang bersifat partikular. Proses universalisasi tersebut mengandaikan dua hal sekaligus: pertama, proses distilasi dan abstraksi nilai-nilai abstrak yang bersifat universal dalam Islam, kedua, mengkonkretkan konteksnya kembali nilai-nilai tersebut dalam konteks kekinian. Dengan demikian, terdapat tiga proses yang harus dilalui, yaitu: embedded, disembedded dan reembedded. Ketiga proses tersebut dapat diilustrasikan sebagai: Islam datang ke tanah Arab, lekat dengan kultur Arab (embedment). Islam itu kemudian diambil dan dilepaskan unsur-unsur Arabnya untuk selanjutnya diambil inti sarinya (disembedment), yang inti sari itu ditanam lagi ke dalam bumi kita sendiri (reembedment). Dalam pandangan post-tradisionalisme Islam, universalisasi Islam bisa diterima jika ia bergerak dalam kerangka siklus tersebut dan universalisasi itu ditolak jika universalisasi itu "loncat" dari Arab ke Jawa, Medan, Madura dan lainnya dengan tanpa melewati proses pelepasan unsur-unsur Arabnya. Dalam kajian Dwijayanto (2017), pribumisasi Islam, kosmopolitanisme Islam, dan universalisme Islam tersebut, pada gilirannya menjadi bagian pembentuk nalar Islam Nusantara yang juga turut berperan penting menjadi rumah besar peradaban pesantren.

Pesantren dengan kaidah al-muhafadhah ala-l-qadim al-shalih wal-akhdzu bi-l-jadid alashlah (memelihara khazanah lama yang baik dan mengambil sesuatu yang baru yang lebih baik) menunjukkan kekayaan intelektualisme yang terbentang mulai zaman Nabi Muhammad saw, zaman klasik, pertengahan hingga zaman modern. Khazanah ini merupakan modal kultural-intelektual yang luar biasa bagi pesantren untuk berdialektika dengan modernitas. Pesantren sebagai lembaga 
asli Indonesia yang memiliki corak tersendiri dibandingkan dengan lembaga lain, mulai dari sistem pengajarannya, transmisi keilmuan dan kebudayaannya serta memiliki peran besar dalam ikut serta mencerdaskan kehidupan bangsa Indonesia (Sahibudin, 2017, p. 145).

Pesantren memiliki satu konsep yang mencakup semua gambaran penting dari model pendidikan. Model ini diformulasikan atas dasar riset empirik, yaitu aspek visioner dalam tujuan pesantren. Tujuan pesantren secara mendasar adalah untuk membangun dan mengembangkan kepribadian muslim yang taat kepada Tuhan dalam kondisi beriman dan bertakwa. Ketaatan ini, selanjutnya akan memancarkan kewajiban moral untuk menyebarkan ajaran dan spirit Islam diantara manusia. Seorang santri bertujuan untuk menjadi muslim yang benar dengan menjaga orientasi hidupnya kepada yang suci dengan menekankan sikap normatif dan ideal atas dasar fikih. Selanjutnya, dalam implementasi-implementasi sikap idealistik dalam kehidupan harian, santri harus menjauhi godaan-godaan material, sikap-sikap dan tendensi keduniawian. Nurcholis Madjid dalam Nata (2001, p. 13) menjelaskan setidaknya ada dua belas prinsip yang melekat pada pendidikan pesantren yaitu : (1) teosentrik, (2) ikhlas, (3) kearifan (4) kesederhanaan (5) kolektifitas (berakhlakuk jamaah) (6) mengatur kegiatan bersama, (7) kebebasan terpimpin (8) kemandirian (9) tempat menuntut ilmu dan mengabdi (thalabul ilmi lil'ibadah), (10) mengamalkan ajaran agama, (11) belajar di pesantren untuk mencari sertifikat/ ijazah saja, dan (12) kepatuhan kepada kiai.

Dengan pola seperti ini, diyakini pula akan memunculkan sikap mental positif dalam diri santri sehingga akan membentuk sebuah sikap kolektivitas yang menjadi dasar terwujudnya culture value system (sistem nilai budaya) yaitu suatu rangkaian dari konsepsi-konsepsi abstrak yang hidup dalam alam pikiran sebagian besar dari seluruh santri, mengenai tidak saja apa yang dianggap penting dan berharga, tetapi juga mengenai apa yang dianggap remeh dan tak berharga dalam hidup.

Dengan demikian, sistem nilai budaya tidak saja berfungsi sebagai suatu pedoman tetapi juga suatu pendorong kelakuan santri dalam kehidupannya, sehingga berfungsi juga sebagai suatu sistem tata yang tertinggi di antara yang lain, seperti hukum adat, aturan sopan santun dan sebagainya. Di dalam fungsinya sebagai pedoman kelakuan dan tata kelakuan, maka sama halnya dengan hukum. Suatu sistem nilai budaya itu seolah-olah berada di luar dan di atas diri individu dalam komunitas sosial pesantren yang bersangkutan. Para santri yang telah diresapi dengan nilai-nilai budaya tersebut, sukar sekali untuk diganti dengan nilai-nilai budaya yang lain dalam waktu yang singkat (Sajogyo \& Sajogyo, 1995, p. 8).

Pesantren, bagaimanapun juga masih menjaga fungsi-fungsi sosial dan kultural yang asli di tengah-tengah masyarakat Indonesia sebagai bagian inheren dari tugas dan tanggung jawab historis. Oleh karena itu, pesantren sebagai sebuah institusi pendidikan dapat menjadi suatu budaya tandingan yang produktif terhadap elemen-elemen budaya modern yang merendahkan nilai sosial dan idealitas spiritual. Fungsi sosio-kultural bermakna bahwa eksistensi pesantren dapat menjadi "center of significance". Pesantren bersama dengan alatnya dapat menjadi model pengetahuan dan sekolah kehidupan yang non-dualistik seperti sebuah simbol kohesi sosial dan juga instrumen profetik dalam berhubungan dengan perubahan sosial di dunia modern. Elemen-elemen modern seperti pengetahuan yang mendalam, dualisme, materialisme, ideologi perkembangan, dan sejenisnya tentu bertentangan dengan pandangan hidup holistik pesantren. 


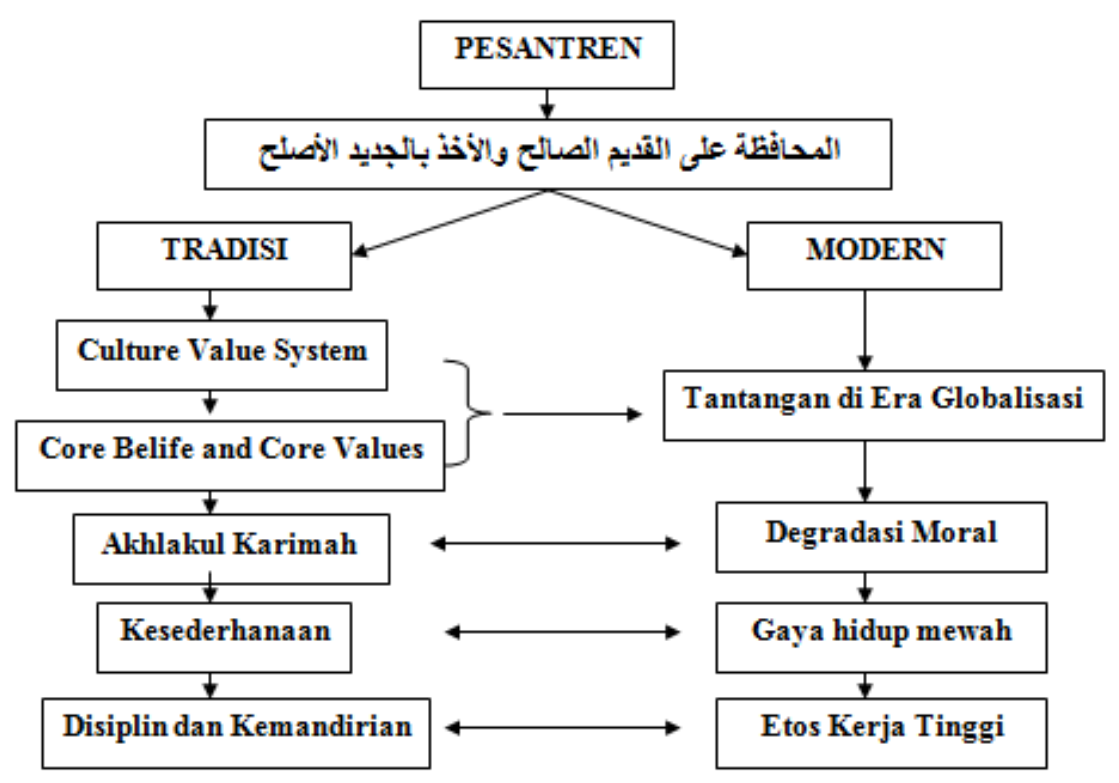

Gambar 3. Tantangan Tradisi Pesantren di Tengah Gempuran Modernitas

\section{Penutup}

Kesimpulan dalam penelitian ini yaitu: 1) Tradisi-tradisi yang telah berkembang di pesantren salaf merupakan akumulasi interpretasi yang telah diwariskan para leluhur sebagai khazanah kejiwaan manusia (al-makhzun al-nafs) yang menjadi pedoman dan piranti dalam lingkungan pesantren; dan 2) analisis dekonstruksi tradisi pesantren salaf dilakukan dengan memutuskan hubungan epistemologis terhadap segala otoritas yang membentuk tradisi pengetahuan dengan merombak sistem relasi yang baku dan beku, menjadi sistem relasi yang cair dan berubah-ubah, dari yang mutlak menjadi relatif, dari ahistoris menjadi historis yang selanjutnya dipertanggungjawabkan untuk memberi sisi-sisi masuk akal (reasonable) dalam segenap tradisi yang berkembang di pesantren salaf. Dalam perkembangan berikutnya, tradisi-tradisi yang telah berkembang tersebut tidak lagi dapat dipandang kolot dan jumud oleh para orientalis maupun pihak lainnya serta dapat meningkatkan ghirah dalam merevitalisasi tradisi pesantren sebagai basis transformasi di era modern agar semakin gencar dibumikan di berbagai lini.

Usaha untuk mengukuhkan tradisi pesantren menjadi keharusan yang perlu dipertahankan karena melihat perkembangan zaman. Di antara ciri tradisi yang perlu dipertahankan ialah pengajaran kitab kuning, kontrol sosial, dan pembentukan pribadi muslim yang paripurna yang lebih menekankan aspek moral, pentingnya pendidikan moral inilah yang menjadi corak karakter pesantren sebagai aset filterisasi terhadap arus modernisasi yang lebih mengedepankan aspek materialisme dan hedonisme (hidup bermewah-mewahan).

Sebagai upaya saran kepada pembaca dan peneliti lain, khususnya pengkaji pesantren, penulis menyadari dengan keterbatasan metode dan sumber data tentu belum banyak analisis yang ditemukan dalam penelitian ini. Semoga penelitian awal ini menjadi spirit lebih lanjut untuk mengembangkan kajian tradisi pesantren dari kacamata metode atau pendekatan yang lain. Semoga temuan awal ini menjadikan pesantren di Indonesia semakin tegak berdiri dengan percaya diri untuk mengembangkan tradisinya masing-masing. Diharapkan juga temuan ini menjadi counter untuk 
menghalau laju pemikiran-pemikiran "kolonial” yang menyerang pesantren dengan tradisinya di era modern ini.

\section{Daftar Pustaka}

Barthes, R. (2004). Mitologi. Yogyakarta: Kreasi Wacana.

Dwijayanto, A. (2017). PRIBUMISASI ISLAM NUSANTARA: ANTARA NALAR BERAGAMA DAN GERAKAN SOSIAL KEAGAMAAN DI INDONESIA. QALAMUNA: Jurnal Pendidikan, Sosial, Dan Agama, 9(02), 71-92. https://doi.org/10.37680/qalamuna.v9i02.342

Fayyadl, M. A.-. (2005). Derrida. Yogyakarta: LkiS.

Foucault, M. (1981). Truth and Power. In C. Gordon (Ed.), Power/Knowledge: Selected Interviews and Other Writings, 1972-1977. Sussex: Harvester Press.

Ghazali, B. (2001). Pendidikan Pesantren Berwawasan Lingkungan. Jakarta: Pedoman Ilmu Jaya.

Hafidhoh, N. (2016). PENDIDIKAN ISLAM DI PESANTREN ANTARA TRADISI DAN TUNTUTAN PERUBAHAN. MUADDIB, 6(1), 88-106.

Hasbullah. (1996). Kapita Selesta Pendidikan Islam di Indonesia. Jakarta: Raja Grafindo Persada.

Hoed, H. B. (2011). Semiotik dan Dinamika Sosial Budaya. Depok: Komunitas Bambu.

Mastud, A. (2002). Pesantren dan Wali Songo. In Dariri Amin (Ed.), Islam dan Kebudayaan Jawa, Yogyakarta. Yogyakarta: Gajah Mada University Press.

Mastuhu. (1994). Dinamika Sistem Pendidikan Pesantren. Jakarta: INIS.

Mukhibat. (2015). Meneguhkan Kembali Budaya Pesantren dalam Merajut Lokalitas, Nasionalitas, dan Globalitas. Karsa, 23(156), 177-192. https://doi.org/10.19105/karsa.v2312.717

Muzakki, H. (2017). WACANA KEAGAMAAN REMAJA DI MEDIA SOSIAL (Kajian Analisis Wacana Model Van Dijk dalam Tulisan Afi). As-Salam, VI(2).

Nata, A. (2001). Sejarah Perkembangan dan Pertumbuhan Lembaga-Lembaga Pendidikan Islam di Indonesia. Jakarta: Grasindo.

Nisa, K. M. (2018). GLOKALISASI: MEMBANGUN PENDIDIKAN GLOBAL BERBASIS KEARIFAN LOKAL PADA PONDOK MODERN. AN-NUHA, 5(1).

Pengurus. (2019). SELAYANG PANDANG.

Rahmat, I. (2003). Islam Pribumi: Mencari Wajah Islam Indonesia. Jakarta: Tashwirul Afkar.

Rohmatulloh, D. (2018). Peta Dinamika Dakwah dalam Mobilitas Muslim Indonesia di Abad ke-20. MUHARRIK: Jurnal Dakwah Dan Sosial, 1(01), 86-96. https://doi.org/10.5281/zenodo.3545043

Sahibudin. (2017). RELEVANSI SISTEM PENDIDIKAN PESANTREN TRADISIONAL DALAM ERA MODERNISASI (Studi Kasus Ponpes Miftahul Ulum Bettet Pamekasan). AlUlum, 4(1), 145-162.

Sajogyo, \& Sajogyo, P. (1995). Sosiologi Pedesaan. Yogyakarta: Gajah Mada University Press. 
Saleh, F. (2004). Teologi Pembaruan: Pergeseran Wacana Islam Sunni di Indonesia Abad XX. Jakarta: Serambi.

Suyatno. (2012). DEKONSTRUKSI PENDIDIKAN ISLAM SEBAGAI SUBSISTEM PENDIDIKAN NASIONAL. Jurnal Pendidikan Islam, I.

Thonthowi. (2008). PENDIDIKAN DAN TRADISI (Menakar Tradisi Pendidikan Pesantren). Tadris, 3(2). 